\title{
Evaluation of prenatal care in unit with family health strategy
}

\author{
AVALIAÇÃO DAASSISTÊNCIA PRÉ-NATAL EM UNIDADE COM ESTRATÉGIA SAÚDE \\ DA FAMÍLIA
}

\section{EVALUACIÓN DEL CUIDADO PRENATAL EN UNIDAD CON ESTRATEGIA SALUD DE LA FAMILIA}

\author{
Marianne Dias Corrêa ${ }^{1}$, Maria Alice Tsunechiro², Marlise de Oliveira Pimentel Lima ${ }^{3}$, \\ Isabel Cristina Bonadio ${ }^{4}$
}

\begin{abstract}
We analyzed prenatal care (PN) provided at a unit of the Family Health Strategy Service in São Paulo, according to the indicators of the Program for the Humanization of Prenatal and Birth (PHPB). We compared adequacy of PN in terms of sociodemographic variables, procedures, examinations and maternal and perinatal outcomes. Crosssectional study with data from records of 308 pregnant women enrolled in 2011. We observed early initiation of PN (82.1\%), conducting of a minimum of six consultations (84.1\%), puerperal consultation (89.0\%); to the extent that there is a sum of the actions, there is a significant drop in the proportion of adequacy. Prenatal care was adequate for $67.9 \%$, with a significant difference between adequacy groups in relation to gestational age and birth weight. Prenatal care deficiencies exist, especially in regards to registration of procedures, exams and immunization. The difference between adequacy groups with respect to perinatal outcomes reinforces the importance of prenatal care that adheres to the parameters of the PHPB.
\end{abstract}

\section{DESCRIPTORS}

Prenatal care

Indicators of quality in health care

Obstetric Nursing

\section{RESUMO}

Analisou-se a assistência pré-natal (PN) de uma unidade com Estratégia Saúde da Família do Município de São Paulo, conforme os indicadores do Programa de Humanização do Pré-Natal e Nascimento (PHPN), e comparou-se adequação do PN com variáveis sociodemográficas, procedimentos, exames e desfechos maternos e perinatais. Estudo transversal com dados de registros de 308 gestantes inscritas em 2011. Observou-se início precoce do PN $(82,1 \%)$, realização do mínimo de seis consultas $(84,1 \%)$, consulta puerperal $(89,0 \%)$ e, à medida que há um somatório das ações, há uma queda importante na proporção de adequação. O PN foi adequado para $67,9 \%$, com diferença significante entre os grupos de adequação em relação à idade gestacional e peso ao nascer. No PN existem deficiências, especialmente no registro de procedimentos, exames e imunização. A diferença nos grupos de adequação com relação aos desfechos perinatais reforça a importância de um PN, conforme os parâmetros do PHPN.

\section{DESCRITORES}

Assistência pré-natal

Indicadores de qualidade em assistência à saúde

Enfermagem obstétrica.

\section{RESUMEN}

Se evaluó el prenatal (PN) de un servicio de salud que cuenta con Estratégia Salud de la Familia, de la ciudad de São Paulo, conforme indicadores del Programa de Humanización del Prenatal y Nacimiento (PHPN) y se comparó la adecuación del PN con variables sociodemográficas, procedimientos, exámenes y los resultados maternos y perinatales. Estudio transversal con datos de los registros de 308 embarazadas inscritas en 2011. Se observó el inicio precoz de PN $(82,1 \%)$, realización del mínimo de seis consultas $(84,1 \%)$ y la consulta puerperal $(89 \%)$ y, en la medida en que hay una suma de las acciones, hay una caída significativa en coeficiente de adecuación. EI PN fue adecuado para el $67,9 \%$, con una diferencia significativa entre los grupos de adecuación en relación a la edad gestacional y el peso al nacer. Hay deficiencias en el PN, especialmente en los registro de procedimientos, exámenes y vacunas. La diferencia entre los grupos en adecuación con respecto a los resultados perinatales refuerza la importancia de un PN conforme parámetros del PHPN.

\section{DESCRIPTORES \\ Cuidado prenatal \\ Indicadores de calidad en la atención de salud \\ Enfermería obstétrica}

\footnotetext{
${ }^{1}$ Nurse Midwife. Master's Degree in Sciences, Graduate Program in Nursing of the School of Nursing, University of São Paulo. Fellowship holder CNPq. marianne.correa@usp.br. ${ }^{2}$ Nurse Midwife. Ph.D. Professor of the Department of Maternal-Infant and Psychiatric Nursing of the School of Nursing, at the University of São Paulo. ${ }^{3}$ Nurse Midwife. Ph.D. Professor of the Obstetrics Program of the School of Arts, Sciences and Humanities, University of São Paulo. moplima@usp.br. ${ }^{4}$ Nurse Midwife. Ph.D. Professor of the Department of Maternal-Infant and Psychiatric Nursing of the School of Nursing, University of São
} Paulo. ibonadio@usp.br. 


\section{INTRODUCTION}

Prenatal care (PN) may contribute to more favorable maternal and perinatal outcomes by enabling early detection and timely treatment of various diseases; in addition to the control of some risk factors that cause complications to women's health and that of newborns ${ }^{(1)}$.

In Brazil, although infant mortality rates have decreased in recent decades, this decline has been uneven across states and municipalities, as well as between areas of a specific municipality ${ }^{(2,3)}$. To improve national rates and decrease these regional differences, the Brazilian government has taken several measures to increase women's access to prenatal care, in order to qualify the actions developed within it and to modify the model of health care for deliveries.

For pregnant women of normal risk, the Program for Humanization of Prenatal and Birth (PHPB) established basic rules for qualified and humanized care, recommending a first prenatal care consultation before the fourth month of pregnancy, at least six prenatal visits (one in the first trimester of pregnancy, two in the second and three in the third), and puerperal consultation until 42 days after birth ${ }^{(4)}$.

Furthermore, in the city of São Paulo, with the goal of improving the quality of maternal-infant care, the Network for the Protection of the Paulistana Mother (Rede de Proteção à Mãe Paulistana) was created in $2006^{(5)}$, which works by way of articulation, integration and monitoring of ambulatory healthcare services as well as municipal and state hospitals. This program aims to ensure: registration and connection of pregnant women to primary healthcare units (PHU) near their homes; inclusion of pregnant women exclusively in the primary healthcare network, regulating the entry point into the healthcare system; linking of pregnant women to reference hospitals in their region and means of transport.

Despite the expansion of teams in the Family Health Strategy Service (FHSS) in the municipal healthcare system in São Paulo, the most recent study that evaluated the quality of the prenatal care network occurred in the mid-2000s ${ }^{(6)}$, and did not specifically focus on primary care. Therefore, there is a knowledge gap, especially in the regions of greatest vulnerability in São Paulo. Recent studies indicate that prenatal care offered by FHSS teams is more in line with the regulations of the PHPB than in the PHU, which has a more traditional organization ${ }^{(7,8)}$.

The objectives of this study were therefore constituted as follows: to analyze the healthcare process of $\mathrm{PN}$ in a unit of the FHSS, in accordance with the indicators of the PHPB, and compare the adequacy of the PN with sociodemographic variables, clinical procedures and obstetrics, examinations and maternal and perinatal outcomes.

\section{METHOD}

This study is part of the project Prenatal assessment in a region of the southern area of São Paulo, funded by the National Council for Scientific and Technological Development - CNPq (Case No. 485.264/2011-0), approved by the Research Ethics Committee of the sponsoring institution and the co-participant - protocol no. 145651 CEP-EEUSP and protocol no. 156805 CEP-SMS. This is a cross-sectional study on prenatal care offered within the scope of the FHSS in a PHU in the Capão Redondo district in the southern area of São Paulo.

In 2011, the Capão Redondo discovered had a population of about 270,000 , with an infant mortality rate of 12.4 per 1,000 live births and $10.0 \%$ of live births weighing less than $2,500 \mathrm{~g}^{(9)}$. A maternal mortality report for the biennium 2009/2010 showed that the maternal mortality ratio (MMR) was 41.4 per 100,000 live births, twice the rate considered to be acceptable by the World Health Organization ${ }^{(10)}$. In order to provide health care to this population, the district depends on 12 PHUs organized into 75 FHSS teams, which are managed by a civil nonprofit partner.

The PHU studied consists of nine FHSS teams; at the time of data collection, the staff included a manager, a nurse, an administrative assistant, four family physicians, nine clinical nurses, 18 nursing assistants, 54 community health agents (CHA) and two dentists. In addition to these professionals, the unit also depends on the Support Center for Family Health (SCFH) (NASF - Núcleo de Apoio à Saúde da Família), composed of a social worker, nutritionist, psychologist, physical trainer and physical therapist. Despite having adequate physical resources, materials, equipment and essential medications, a deficiency in human resources remained, lacking five doctors.

The study population consisted of 392 women enrolled in SISPRENATAL in 2011, whose medical records were located. In the final sample of 308 women, 84 were excluded: 2 for pregnancy not confirmed; 35 for abortion; and 47 who discontinued $\mathrm{PN}$ at the PHU at a gestational age of $<30$ weeks).

Data were obtained from prenatal registration forms and SISPRENATAL evolution sheets utilized at the PHU. Data collection was conducted between December 2012 and March 2013, using a specific form. The extraction method and data recording were standardized by means of an instruction manual, in order to reduce determination bias and increase homogeneity in the collection.
Evaluation of prenatal care in unit with family health strategy Corrêa MD, Tsunechiro MA , Lima MOP, Bonadio IC 
The data were stored in the Excel 2010 (Microsoft Corporation), using double entry, for the assessment of agreement and error checking.

The criteria used in the analysis of the process of PN and puerperal care, in accordance with indicators of the PHPB, ${ }^{(4)}$ were: 1 ) started by the 16 th week; 2 ) minimum of six visits; 3 ) puerperal consultation; 4) started by the 16th week and a minimum of six visits; 5) started by the 16 th week, minimum of six visits and postpartum consultation; 6) started by the 16th week, minimum of six visits and basic tests -- blood typing ( $\mathrm{ABO} / \mathrm{Rh}$ ) in the first consultation, syphilis testing (VDRL) at the first visit and 30th week, and anti-HIV in the first consultation, $\mathrm{Hb} / \mathrm{Ht}$ in the first consultation, blood glucose at first visit and 30th week, urinalysis (USA - Urinary Sediment Abnormalities) at the first visit and 30th week; 7) started by the 16th week, minimum of six visits, basic exams and puerperal consultation; 8) started by the 16th week, minimum of six visits, basic exams, puerperal consultation and immunizing dose of tetanus vaccine; 9) immunizing dose of tetanus vaccine; 10 ) at least one visit in the first quarter, two in the second and three in the third.

In order to classify PN (adequate and inadequate) and compare groups, adherence to the following three indicators of the PHPB was considered: started by the 16th week, minimum of six consultations in PN and realization of puerperal consultation.

The variables analyzed in the comparison between the adequacy groups were sociodemographic: age, race/ethnicity, education, family status and paid work; obstetric and clinical procedures: calculation of gestational age, weighing, measurement of blood pressure (BP) measurement of Fundal height (UH), Fundal height chart by gestational age, auscultation of fetal heart rates (FHR) and assessing pregnancy risk. Clinical and obstetric procedures were considered to have taken place when there was a record of all consultations and partial if this criterion was not met. For the first record of Fundal height and of fetal heart rate, the gestational ages were considered from the 13th and 14th weeks, respectively.

Additionally, in the analysis comparing the adequate and inadequate PN groups, beyond the examinations observed following the criteria of the PHPB, the records of these tests were used: anti-HIV in the 30th week, serology for hepatitis B ( $\mathrm{HBsAg}$ ) and toxoplasmosis (IgG and IgM ), $\mathrm{Hb} / \mathrm{Ht}$ in the 30th week, urine culture at the first visit and at the 30th week; and for maternal and perinatal outcomes the variables: type of delivery, gestational age at birth, birth weight and breastfeeding.

Descriptive analysis of variables was performed and data were grouped into absolute and relative frequencies, and measured for the central tendency. In order to compare the groups of adequacy of the PN, we used the Chi-squared test using the Statistical Package for Social Science version 13.0; values of $p<0.05$ were considered to be statistically significant.

\section{RESULTS}

The mean gestational age at start of prenatal care was 10.8 (SD 7.3) weeks, with a mean of 8.4 (SD 2.8) consultations. Table 1 shows that the vast majority (82.1\%) of women began PN monitoring by the 16th week of pregnancy; $84.1 \%$ had at least a minimum of six consultations and $89.0 \%$ had a postpartum consultation. In total, 209 (67.9\%) women were classified as receiving adequate $\mathrm{PN}$ and, therefore 99 (32.1\%) received inadequate PN according to the criteria adopted: started by 16 th week of gestation, at least six prenatal consultations and a postpartum consultation. Table 1 also indicates that, to the extent that actions recommended by the PHPB are summed, there is a significant drop in the proportion of the record, especially in the case of basic exams.

There was no difference between the adequacy groups of PN according to sociodemographic characteristics (Table 2).

Table 1 - Evaluation of the process of prenatal and postpartum care, according to the indicators of the PHPB, Sao Paulo, 2013

\begin{tabular}{|c|c|c|}
\hline Prenatal and Postpartum Care & $\mathbf{N}$ & $\%$ \\
\hline Started by 16th week of gestation & 253 & 82.1 \\
\hline Minimum of six prenatal consultations & 259 & 84.1 \\
\hline Postpartum consultation & 274 & 89.0 \\
\hline Started by 16th week of gestation and at least six prenatal consultations & 234 & 76.0 \\
\hline Started by the 16th week of gestation, at least six prenatal consultations and a postpartum consultation. & 209 & 67.9 \\
\hline Started by the 16th week of gestation, at least six prenatal consultations and record of all the basic exams. & 50 & 16.2 \\
\hline $\begin{array}{l}\text { Started by the } 16 \text { th week of gestation, at least six prenatal consultations, record of all the basic exams and a postpartum } \\
\text { consultation. }\end{array}$ & 41 & 13.3 \\
\hline $\begin{array}{l}\text { Started by the } 16 \text { th week of gestation, at least six prenatal consultations, record of all the basic exams, a postpartum consul- } \\
\text { tation and immunization dose of the tetanus vaccine. }\end{array}$ & 30 & 9.7 \\
\hline Immunization dose of the tetanus vaccine. & 208 & 67.5 \\
\hline At least one consultation in the 1 st quarter, two in the 2 nd and three in the $3 \mathrm{rd} *$ & 196 & 63.6 \\
\hline
\end{tabular}

* 1 st trimester $=$ up to 13 weeks, 2 nd trimester $=14$ to 27 weeks, 3rd trimester $\geq 28$ weeks $^{(11)}$. 
Table 2 - Sociodemographic characteristics of the women, according to the adequacy groups of prenatal care, São Paulo, 2013.

\begin{tabular}{|c|c|c|c|c|c|c|c|}
\hline \multirow{2}{*}{ Variables } & \multicolumn{2}{|c|}{ Adequate PN } & \multicolumn{2}{|c|}{ Inadequate PN } & \multicolumn{2}{|c|}{ Total } & \multirow{2}{*}{$p^{*}$} \\
\hline & $\mathbf{N}$ & $\%$ & $\mathbf{N}$ & $\%$ & $\mathbf{N}$ & $\%$ & \\
\hline \multicolumn{8}{|l|}{ Age } \\
\hline$<20$ & 52 & 24.9 & 17 & 17.3 & 69 & 22.5 & 0.160 \\
\hline 20 to 34 & 135 & 64.6 & 74 & 75.6 & 209 & 68.1 & \\
\hline$>35$ & 22 & 10.5 & 7 & 7.1 & 29 & 9.4 & \\
\hline \multicolumn{8}{|c|}{ Ethnicity/Skin color } \\
\hline White & 71 & 34.6 & 36 & 37.1 & 107 & 35.4 & 0.582 \\
\hline Black/Mulatto & 132 & 64.4 & 61 & 62.9 & 193 & 63.9 & \\
\hline Yellow & 2 & 1.0 & 0 & 0.0 & 2 & 0.7 & \\
\hline \multicolumn{8}{|l|}{ Education } \\
\hline 0 to 7 years & 65 & 33.5 & 38 & 40.9 & 103 & 35.9 & 0.224 \\
\hline$\geq 8$ years & 129 & 66.5 & 55 & 59.1 & 184 & 64.1 & \\
\hline \multicolumn{8}{|l|}{ Family situation } \\
\hline Partner/children & 146 & 75.6 & 68 & 72.3 & 214 & 74.6 & 0.546 \\
\hline Without partner & 47 & 24.4 & 26 & 27.7 & 73 & 25.4 & \\
\hline \multicolumn{8}{|l|}{ Paid work } \\
\hline Yes & 100 & 49.8 & 43 & 44.8 & 143 & 48.1 & 0.424 \\
\hline No & 101 & 50.2 & 53 & 55.2 & 154 & 51.9 & \\
\hline
\end{tabular}

${ }^{*}$ Chi-square Test

The data in Table 3 show that, despite a higher percentage of recording of procedures in the consultations (Concluded) of women with adequate PN, there was no statistically

significant difference between the groups. Moreover, we can see that, regardless of the adequacy of the PN, there was not a $100 \%$ record for any procedure being studied.

Table 3 - Procedures registered in the medical record (considered to be carried out when there was a record in all consultations), according to the adequacy groups of prenatal care, São Paulo, 2013.

\begin{tabular}{|c|c|c|c|c|c|c|c|}
\hline \multirow{2}{*}{ Variables } & \multicolumn{2}{|c|}{ Adequate PN } & \multicolumn{2}{|c|}{ Inadequate PN } & \multicolumn{2}{|c|}{ Total } & \multirow{2}{*}{$p^{*}$} \\
\hline & $\mathbf{N}$ & $\%$ & $\mathbf{N}$ & $\%$ & $\mathbf{N}$ & $\%$ & \\
\hline \multicolumn{8}{|c|}{ Gestational Age } \\
\hline Carried out & 206 & 98.6 & 95 & 96.0 & 301 & 97.7 & 0.152 \\
\hline Partial & 3 & 1.4 & 4 & 4.0 & 7 & 2.3 & \\
\hline \multicolumn{8}{|l|}{ Weighing } \\
\hline Carried out & 205 & 98.1 & 93 & 93.9 & 298 & 96.8 & 0.055 \\
\hline Partial & 4 & 1.9 & 6 & 6.1 & 10 & 3.2 & \\
\hline \multicolumn{8}{|c|}{ Blood pressure } \\
\hline Carried out & 207 & 99.0 & 95 & 97.0 & 302 & 98.4 & 0.174 \\
\hline Partial & 2 & 1.0 & 3 & 3.0 & 5 & 1.6 & \\
\hline \multicolumn{8}{|c|}{ Fundal height } \\
\hline Carried out & 170 & 81.7 & 86 & 86.9 & 256 & 83.4 & 0.258 \\
\hline Partial & 38 & 18.3 & 13 & 13.1 & 51 & 16.6 & \\
\hline \multicolumn{8}{|c|}{ Fundal height graph } \\
\hline Carried out & 1 & 0.8 & 0 & 0.0 & 1 & 0.6 & 0.540 \\
\hline Partial & 117 & 99.2 & 44 & 100.0 & 161 & 99.4 & \\
\hline \multicolumn{8}{|c|}{ Fetal heart rate } \\
\hline Carried out & 179 & 86.1 & 90 & 91.0 & 269 & 87.6 & 0.228 \\
\hline Partial & 29 & 13.9 & 9 & 9.0 & 38 & 12.4 & \\
\hline \multicolumn{8}{|c|}{ Assessment of gestational risk } \\
\hline Carried out & 150 & 71.8 & 72 & 72.7 & 222 & 72.1 & 0.861 \\
\hline Partial & 59 & 28.2 & 27 & 27.3 & 86 & 27.9 & \\
\hline
\end{tabular}

${ }^{*}$ Chi-square Test 
The data in Table 4 show that there is a significant

the recording of exams, with the exception of $\mathrm{Hb} / \mathrm{Ht}$ difference between the adequacy groups of the PN in and USA, both from the 30th week.

Table 4 - Exams registered in the medical records, according to the adequacy groups of prenatal care, São Paulo, 2013.

\begin{tabular}{|c|c|c|c|c|c|c|c|}
\hline \multirow{2}{*}{ Variables } & \multicolumn{2}{|c|}{ Adequate PN } & \multicolumn{2}{|c|}{ Inadequate PN } & \multicolumn{2}{|c|}{ Total } & \multirow{2}{*}{$p^{*}$} \\
\hline & $\mathbf{N}$ & $\%$ & $\mathbf{N}$ & $\%$ & $\mathbf{N}$ & $\%$ & \\
\hline \multicolumn{8}{|l|}{$\mathrm{ABO} / \mathrm{Rh}$} \\
\hline Recorded & 205 & 98.1 & 88 & 88.9 & 293 & 95.1 & 0.000 \\
\hline No & 4 & 1.9 & 11 & 11.1 & 15 & 4.9 & \\
\hline \multicolumn{8}{|l|}{ VDRL } \\
\hline Recorded & 205 & 98.1 & 80 & 80.8 & 285 & 92.5 & 0.000 \\
\hline No & 4 & 1.9 & 19 & 19.2 & 23 & 7.5 & \\
\hline \multicolumn{8}{|c|}{ VDRL 30th week } \\
\hline Recorded & 150 & 71.8 & 49 & 49.5 & 199 & 64.6 & 0.000 \\
\hline No & 59 & 28.2 & 50 & 50.5 & 109 & 35.4 & \\
\hline \multicolumn{8}{|l|}{ HIV } \\
\hline Recorded & 200 & 95.7 & 79 & 79.8 & 279 & 90.6 & 0.000 \\
\hline No & 9 & 4.3 & 20 & 20.2 & 29 & 9.4 & \\
\hline \multicolumn{8}{|c|}{ HIV 30th week } \\
\hline Recorded & 146 & 69.9 & 46 & 46.5 & 192 & 62.3 & 0.000 \\
\hline No & 63 & 30.1 & 53 & 53.5 & 116 & 37.7 & \\
\hline \multicolumn{8}{|l|}{ HBsAg } \\
\hline Recorded & 201 & 96.2 & 84 & 84.8 & 285 & 92.5 & 0.000 \\
\hline No & 8 & 3.8 & 15 & 15.2 & 23 & 7.5 & \\
\hline \multicolumn{8}{|c|}{ Toxoplasmosis serology } \\
\hline Recorded & 198 & 94.7 & 83 & 83.8 & 281 & 91.2 & 0.002 \\
\hline No & 11 & 5.3 & 16 & 16.2 & 27 & 8.8 & \\
\hline \multicolumn{8}{|l|}{$\mathrm{Hb} / \mathrm{Ht}$} \\
\hline Recorded & 208 & 99.5 & 76 & 76.8 & 284 & 92.2 & 0.000 \\
\hline No & 1 & 0.5 & 23 & 23.2 & 24 & 7.8 & \\
\hline \multicolumn{8}{|c|}{ Hb/Ht 30th week } \\
\hline Recorded & 65 & 31.1 & 29 & 29.3 & 94 & 30.5 & 0.748 \\
\hline No & 144 & 68.9 & 70 & 70.7 & 214 & 69.5 & \\
\hline \multicolumn{8}{|c|}{ Urinalysis (USA) } \\
\hline Recorded & 206 & 98.6 & 81 & 81.8 & 287 & 93.2 & 0.000 \\
\hline No & 3 & 1.4 & 18 & 18.2 & 21 & 6.8 & \\
\hline \multicolumn{8}{|c|}{ USA 30th week } \\
\hline Recorded & 61 & 29.2 & 22 & 22.2 & 83 & 27.0 & 0.198 \\
\hline No & 148 & 70.8 & 77 & 77.8 & 225 & 73.0 & \\
\hline \multicolumn{8}{|c|}{ Urine culture } \\
\hline Recorded & 197 & 94.3 & 76 & 76.8 & 273 & 88.6 & 0.000 \\
\hline No & 12 & 5.7 & 23 & 23.2 & 35 & 11.4 & \\
\hline \multicolumn{8}{|c|}{ Urine culture 30 th week } \\
\hline Recorded & 157 & 75.1 & 50 & 50.5 & 207 & 67.2 & 0.000 \\
\hline No & 52 & 24.9 & 49 & 49.5 & 101 & 32.8 & \\
\hline \multicolumn{8}{|l|}{ Glycemia } \\
\hline Recorded & 206 & 98.6 & 81 & 81.8 & 287 & 93.2 & 0.000 \\
\hline No & 3 & 1.4 & 18 & 18.2 & 21 & 6.8 & \\
\hline \multicolumn{8}{|c|}{ Glycemia 30th week } \\
\hline Recorded & 160 & 76.6 & 49 & 49.5 & 209 & 67.9 & 0.000 \\
\hline No & 49 & 23.4 & 50 & 50.5 & 99 & 32.1 & \\
\hline
\end{tabular}


Table 5 shows that the adequate group of PN obtained better outcomes in relation to gestational age and birth weight.

Table 5 - Maternal and perinatal outcomes, according to the adequacy of prenatal care, São Paulo, 2013.

\begin{tabular}{|c|c|c|c|c|c|c|c|}
\hline \multirow[t]{2}{*}{ Outcome } & \multicolumn{2}{|c|}{$\begin{array}{c}\text { Adequate } \\
\text { PN }\end{array}$} & \multicolumn{2}{|c|}{$\begin{array}{c}\text { Inadequate } \\
\text { PN } \\
\end{array}$} & \multicolumn{2}{|c|}{ Total } & \multirow[t]{2}{*}{$p^{*}$} \\
\hline & $\mathbf{N}$ & $\%$ & $\mathbf{N}$ & $\%$ & $\mathbf{N}$ & $\%$ & \\
\hline \multicolumn{8}{|l|}{ Type of delivery } \\
\hline $\begin{array}{l}\text { Normal and } \\
\text { forceps }\end{array}$ & 133 & 64.6 & 44 & 66.7 & 177 & 65.1 & 0.755 \\
\hline Cesarean section & 73 & 35.4 & 22 & 33.3 & 95 & 34.9 & \\
\hline \multicolumn{8}{|l|}{$\begin{array}{l}\text { Gestational age } \\
\text { at birth }\end{array}$} \\
\hline$\geq 37$ weeks & 179 & 93.7 & 49 & 84.5 & 218 & 91.2 & 0.037 \\
\hline$<37$ weeks & 12 & 6.3 & 9 & 15.5 & 21 & 8.8 & \\
\hline \multicolumn{8}{|l|}{ Birthweight } \\
\hline $\begin{array}{l}\geq 2,500 \mathrm{~g} \text { to } \\
4,000 \mathrm{~g}\end{array}$ & 185 & 91.1 & 57 & 81.4 & 242 & 88.6 & 0.027 \\
\hline$<2,500 \mathrm{~g}$ & 18 & 8.9 & 13 & 18.6 & 31 & 11.4 & \\
\hline \multicolumn{8}{|l|}{ Breast-feeding } \\
\hline Yes & 189 & 94.0 & 63 & 98.4 & 252 & 95.1 & 0.155 \\
\hline No & 12 & 6.0 & 1 & 1.6 & 13 & 4.9 & \\
\hline
\end{tabular}

\section{DISCUSSION}

In Brazil, improvement in quality of prenatal care could prevent maternal and infant deaths that are considered to be preventable. Thus, evaluation of healthcare services is important for the qualification of the healthcare provided.

As an essential action, PHPB provides for early inclusion of the pregnant women for the first PN consultation, set for 16 weeks of gestation. In this study, we found that the proportion of pregnant women enrolled in SISPRENATAL who adhered to this recommendation was higher than that found in a study in Rio de Janeiro and similar to that of a study from João Pessoa - 74.4\% to $83.6 \%^{(1,12)}$. However, it was lower than Botucatu, which ranged from $86.0 \%$ to $93.0 \%$, ${ }^{(13)}$ and Araguari, with $91.7 \%^{(14)}$. The number of six or more visits during PN was superior to several recent studies, which found $79.2 \%^{(1)} 80.0$ to $74.0 \%^{(15)}, 80.0 \%^{(13)}$ and $80.4 \%^{(16)}$, but lower than that of João Pessoa, with $89.9 \%{ }^{(12)}$ and Botucatu, with $94.0 \%$ in the FHSS and $97.0 \%$ in the traditional $\mathrm{PHU}^{(13)}$. Also, the combination of an early start of $\mathrm{PN}$ and conducting six consultations was higher than that found in two studies, one in São Paulo, at $63.1 \%{ }^{(17)}$ and another in Recife, at $38.0 \%{ }^{(18)}$.

The results suggest that the actions of the PHU for the involvement and adherence of pregnant women to followup throughout pregnancy are satisfactory, but need to be improved in order to increase the proportion of early start $\mathrm{PN}$, combined with the minimum number of consultations recommended by the PHPB. The PHU in question provides healthcare services by way of the FHSS, which rearranges the care model in primary care, operationalized by way of the work of multidisciplinary teams responsible for a set number of families located in a defined geographical area. The responsibility of the FHSS and the interaction with each person and their family have the purpose of generating changes in the health-disease process, contributing to better results in health ${ }^{(7)}$.

Puerperal consultation is among the indicators of quality of PN by way of the PHPB. However, few studies have analyzed puerperal return, an occasion to evaluate recovery of women in the postpartum period, institute the use of family planning methods, and monitor breastfeeding. Thus, health care for women during pregnancy should only be considered complete after puerperal consultation ${ }^{(19)}$. The National Survey on Demography and Health (2006) (20) showed that women attend a postpartum consultation in only $29 \%$ of births, emphasizing that this important stage of care has been neglected.

Despite the higher or similar percentage of puerperal consultation compared to that found in other studies ${ }^{(7,13,21)}$, we emphasize the need for attention from staff in order to increase the number of women with puerperal consultations, given the importance of healthcare provided in this period to decreasing maternal and perinatal morbidity and mortality.

A limitation of the present study is that the data were obtained from the medical records of pregnant women, because some actions may have been carried out and not recorded, and this aspect should be considered when interpreting the results.

It is considered, therefore, that errors in the medical records regarding testing and tetanus immunizations may have affected the final outcome of the adequacy of prenatal care. Also, there is a possibility of error in the execution of the tests, due to lack of specific materials, damaged equipment, delay in returning the results and loss of samples, among others. In a study conducted in the metropolitan region of São Paulo, among the hypotheses put forward to explain the low coverage of examinations in the third trimester, it is highlighted that professionals do not request the tests because they are out of the habit, and that some pregnant women fail to take tests even when they have been ordered ${ }^{(22)}$.

The proportion of records of tests found in this study was higher than or similar to other studies ${ }^{(1,7,8)}$, with a decline between the first consultation and the 30 th week. This result is disturbing, as the tests provide information about the health status of pregnant women; they are also important in screening for diseases that could have negative consequences for mothers and fetuses, for example, sexually transmitted diseases such as syphilis, hepatitis B and AIDS, as well as 
anemia, gestational diabetes, maternal-fetal blood incompatibility, asymptomatic bacteriuria of pregnancy and toxoplasmosis. The repetition of some tests is indicated for control of disease remission or verification of its occurrence later in pregnancy.

In Brazil, in 2011, 9,374 new cases of congenital syphilis were reported in infants under one year of age, and there was a congenital syphilis rate of 3.3 cases per 1,000 live births ${ }^{(23)}$. This illness is a clear indicator of the quality of prenatal care, considering that diagnosis and treatment can be performed effectively during pregnancy in primary healthcare services. Considering that, in the third trimester, more than a third of pregnant women were not tested for syphilis, one can question the quality of prenatal care offered at the unit with the FHSS being studied.

There was a significant difference in the recording of examinations between the groups; in the adequate PN group, tests ordered at the first visit were recorded more often. This result reiterates the importance of a health team that is attentive to compliance with the parameters of the PHPB, while also seeking strategies to mitigate difficulties that are inherent in working conditions that compromise the quality of PN care.

Tetanus vaccinations, considered an effective measure in the prevention of neonatal(24) tetanus, has shown low coverage in Brazil $(31 \%)^{(20)}$, in Salvador, $(33.5 \%)^{(25)}$, and Botucatu, $(31.4 \%)^{(26)}$. However, in Curitiba, registration of $87.2 \%$ was observed for application of tetanus vaccine $^{(27)}$. In the present study, just over two thirds $(67.5 \%)$ of the medical records showed that the mother was immune or vaccinated against tetanus. However, efforts are needed for effective coverage by tetanus immunization, not only to eradicate neonatal tetanus, but also as a preventive measure against tetanus in adult women. The opportunity to update the immunization schedule should not be missed, considering that, during pregnancy, women seek healthcare services for PN control.

Considering an early start, a minimum of six consultations and a puerperal consultation, the adequacy of PN reached two thirds of the women (67.9\%). However, when we extended the analysis to include all basic tests recommended in the PHPB and tetanus immunization, that number dropped dramatically to 9.7\%. In Brazil, review of the first years of the PHPB showed that by adding all routine laboratory tests that should be ordered at the beginning of PN, including carrying out of the anti-HIV, less than $5 \%$ was considered adequate in $2002^{(19)}$. Thus, the results found in this study suggest an improvement, but far below the proportion of $21 \%$ reached in Quixadá in $2004^{(28)}$.

The finding of no significant difference between the adequate and inadequate PN groups in relation to sociodemographic variables shows that these characteristics of women were not what influenced adequacy of PN.
Although there was no difference between the adequate and inadequate $\mathrm{PN}$ groups in the records of the procedures, we emphasize that performing and recording the procedures is essential to assess the relevance and adequacy of each of them throughout pregnancy and the correlation between them at each consultation. The results of this study showed that the fundal height chart by gestational age was filled out for only one pregnant woman. It is noteworthy that this instrument, if accurately completed, allows for precise evaluation and directs the conduct taken, especially in situations that deviate from the norm. The evaluation of gestational risk in each consultation is part of the basic conditions for effective prenatal care, but it did not occur in approximately one third of the pregnant women, in both the group of adequate PN and in the inadequate group.

The result that showed a significant difference between the adequate and inadequate $\mathrm{PN}$ groups in perinatal outcomes related to gestational age and birth weight confirms the importance of adequacy of PN. The best perinatal outcomes in the group with adequate PN showed that, although the groups did not differ in terms of sociodemographic characteristics, perinatal outcomes were influenced by the adequacy of PN or lack thereof.

Other studies on quality of prenatal care and favorable perinatal outcomes corroborate these results, although the quality parameters adopted were not the same $e^{(29,30)}$.

\section{CONCLUSION}

The important result obtained in relation to perinatal outcomes according to the adequacy of prenatal care reinforces the importance of contemplating the basic standards recommended by the PHPB in order to provide qualified and humane healthcare services.

Prenatal care in the FHSS analyzed showed satisfactory results in relation to the indicators of the PHPB, such as early start, number of prenatal consultations, exams at the first visit and puerperal consultation. Considering that carrying out clinical and obstetric procedures is the foundation of prenatal care, none of the indicators reached $100 \%$, although they reached elevated proportions, except for the fundal height graph. Additionally, deficiencies in care were evidenced, such as failures in recording of procedures, tests and tetanus immunizations, which affect the quality of PN offered.

Considering that the data were collected from medical records, other studies should be conducted so that we can understand how working conditions and individual responsibilities of health professionals influence the recording of the care provided. 


\section{REFERÊNCIAS}

1. Domingues RMSM, Hartz ZMA, Dias MAB, et al. Avaliação da adequação da assistência pré-natal na redeSUS do Município do Rio de Janeiro, Brasil. Cad. Saúde Pública. 2012; 28(3):425-437.

2. IBGE. Brasil em síntese. 2013. Acesso em 20/11/2013. Disponível em: http://brasilemsintese.ibge.gov.br/populacao/ taxas-de-mortalidade-infantil.

3. Prefeitura do Município de São Paulo. Tabela de mortalidade infantil. Acesso em 20/11/2013. Disponível em: http://tabnet. saude.prefeitura.sp.gov.br/cgi/tabcgi.exe?secretarias/saude/ TABNET/minf/mortinf.def.

4. Brasil. Ministério da Saúde. Portaria n. 569, de 01 de junho de 2000. Institui o Programa de Humanização no Pré-natal e Nascimento, no âmbito do Sistema Único de Saúde. In: Diário Oficial da União (DOU), 8 de junho de 2000, seção 1, p.4-6. Brasília;2000.

5. São Paulo. Decreto n. 046.966 de 02 de fevereiro de 2006. Regulamenta a Lei no 13.211 , de 13 de novembro de 2001, estruturando a Rede de Proteção à Mãe Paulistana, para a gestão e execução da rede de serviços de saúde de assistência obstétrica e neonatal no Município de São Paulo. Diário Oficial da Cidade de São Paulo, 3 de fevereiro de 2006, Seção 1, p. 1. São Paulo; 2006.

6. Succi RCM, Figueiredo EN, Zanatta LC, et al. Avaliação da assistência pré-natal em unidades básicas do município de São Paulo. Rev Latino-Am Enfermagem. 2008;16(6):986-92.

7. Anversa ETR, Bastos GAN, Nunes LN, et al. Qualidade do processo da assistência pré-natal: unidades básicas de saúde e unidades de Estratégia Saúde da Família em município no Sul do Brasil. Cad. Saúde Pública. 2012;28(4):789-800.

8. Cesar JA, Sutil AT, Gabriela BS, et al. Assistência pré-natal nos serviços públicos de saúde: estudo transversal de base populacional em Rio Grande, Rio Grande do Sul, Brasil. Cad. Saúde Pública. 2012;28(11):2106-2114.

9. Observatório Cidadão Nossa São Paulo. Acesso em 20/11/2013. Disponível em: http://www.nossasaopaulo.org. br/observatorio/regioes. php? regiao $=12 \&$ distrito $=19$

10. São Paulo. Secretaria Municipal da Saúde - Coordenação da Atenção Básica, Área Técnica da Saúde da Mulher. Comitê Central de Mortalidade Materna. Relatório de Mortalidade Materna biênio 2009/2010. São Paulo; 2010. Acesso em 05/03/2013. Disponível em: http://www.prefeitura.sp.gov. $\mathrm{br} / \mathrm{cidade} / \mathrm{secretarias/upload/saude/arquivos/mulher/Rel-}$ MortMaterna0910.pdf

11. Brasil. Ministério da Saúde. Secretaria de Políticas de Saúde. Assistência Pré-Natal: Manual técnico. Brasília: Ministério da Saúde, 2000b.
12. Silva EP, Lima RT, Ferreira NLS, et al. Pré-natal na atenção primária do município de João Pessoa-PB: caracterização de serviços e usuárias. Rev Bras Saúde Matern Infant. 2013;13(1)29-37.

13. Oliveira RLA, Fonseca CRB, Carvalhaes MABL, et al. Avaliação da atenção pré-natal na perspectiva dos diferentes modelos na atenção primária. Rev. Latino-Am. Enfermagem [internet] 2013. [acesso em 23 nov 2013]; 21(2). Disponível em: http://www.scielo.br/scielo.php?pid=S0104$11692013000200546 \&$ script=sci_abstract $\&$ tlng=pt

14. Miranda FJS, Fernandes RAQ. Assistência pré-natal: estudo de três indicadores. Rev. enferm UERJ. 2010;18(2):179-84.

15. Zanchi M, Gonçalves CV, Cesar JÁ, et al. Concordância entre informações do Cartão da Gestante e do recordatório materno entre puérperas de uma cidade brasileira de médio porte. Cad. Saúde Pública. 2013;29(5):1019-1028.

16. Vettore MV, Dias M, Vettore MV, et al. Avaliação da qualidade da atenção pré-natal dentre gestantes com e sem história de prematuridade no Sistema Único de Saúde no Rio de Janeiro, Brasil. Rev Bras Saúde Matern. Infant. 2013;13(2):89-100.

17. Corrêa CRH, Bonadio IC, Tsunechiro MA. Normative prenatal evaluation at a philanthropic maternity hospital in São Paulo. Rev Esc Enferm USP. 2011;45(6):1293-1300.

18. Carvalho VCP, Araújo TVB. Adequação da assistência prénatal em gestantes atendidas em dois hospitais de referência para gravidez de alto risco do Sistema Único de Saúde, na cidade de Recife, Estado de Pernambuco. Rev Bras Saúde Matern. Infant. 2007;7(3):309-317.

19. Serruya SJ, Cecatti JG, Lago TG. O Programa de Humanização no Pré-natal e Nascimento do Ministério da Saúde no Brasil: resultados iniciais. Cad. Saúde Pública. 2004;20(5):1281-1289.

20. Brasil. Ministério da Saúde. Centro Brasileiro de Análise e Planejamento. Pesquisa nacional de demografia e saúde da muIher e da criança PNDS 2006 - relatório final. Brasília; 2008.

21. Gonçalves R, Urasaki MBM, Merighi MAB, et al. Avaliação da efetividade da assistência pré-natal de uma unidade de saúde da família em um município da Grande São Paulo. Rev Bras Enferm. 2008;61(3):349-53.

22. Barbosa MA, Fernandes RAQ. Avaliação da Assistência PréNatal de Baixo Risco no Município de Francisco Morato-SP. Online Braz J Nurs. 2008;7(3).

23. Brasil. Ministério da Saúde. Secretaria de Vigilância em Saúde. Departamento de DST, Aids e Hepatites Virais. Boletim Epidemiológico - Sífilis. Brasília: Ministério da Saúde; 2012. [ISSN: 1517-1159] 
24. Brasil. Ministério da Saúde. Secretaria de Atenção à Saúde. Departamento de Atenção Básica. Caderno de atenção básica no 32: atenção ao pré-natal de baixo risco. Brasília; 2012.

25. Nascimento ER, Paiva MS, Rodrigues PQ. Avaliação da cobertura e indicadores do programa de humanização do prénatal e nascimento no Município de Salvador, Bahia, Brasil. Rev Bras Saúde Matern. Infant. 2007;7(2):191-7.

26. Parada CMGL. Avaliação da assistência pré-natal e puerperal desenvolvidas em região do interior do Estado de São Paulo em 2005. Rev Bras Saúde Matern. Infant. 2008;8(1):113-24.

27. Carvalho DS, Novaes HMD. Avaliação da implantação de programa de atenção pré-natal no Município de Curitiba, Paraná, Brasil: estudo de coorte de primigestas. Cad. Saúde Pública. 2004;20(Sup2):S220-S230.
28. Grangeiro GR, Diógenes MAR, Moura ERF. Prenatal care in Quixadá-CE according to SISPRENATAL process indicators. Rev Esc Enferm USP. 2008;42(1):105-11.

29. Silveira DS, Santos IS. Adequação do pré-natal e peso ao nascer: uma revisão sistemática. Cad. Saúde Pública. 2004;20(5):1160-1168.

30. Wehby GL, Murray JC, Castilla EE, et al. Prenatal care effectiveness and utilization in Brazil. Health Policy Plan. 2009;24:175-88.

\section{Acknowledgments}

The National Council for Scientific and Technological Development (CNPq) for funding the research project (Case No. 485.264/2011-0), from which the study data were extracted. 